\title{
Respiration Rate of Blueberry in Modified Atmosphere at Various Temperatures
}

\author{
Yoonseok Song, Hyun Ku Kim ${ }^{1}$, and Kit L. Yam ${ }^{2}$ \\ Department of Food Science, Cook College New Jersey Agricultural Experiment Station, Rutgers \\ University, New Brunswick, NJ 08903
}

Additional index words. Vaccinium corymbosum, enzyme kinetic model

\begin{abstract}
Respiration rates of three blueberry (Vaccinium corymbosum L.) cultivars (Coville, Blueray, and Jersey) were measured as a function of $\mathrm{O}_{2}, \mathrm{CO}_{2}$, and temperature using the closed system method. The data conformed well to a recently proposed Michaelis-Menten type respiration $(r)$ model $\left(r=\mathbf{V}_{\mathrm{m}}\left[\mathrm{O}_{2}\right] /\left\{\mathrm{K}_{\mathrm{m}}+\left(1+\left[\mathrm{CO}_{2}\right] / \mathrm{K}_{\mathrm{i}}\right)\left[\mathrm{O2}_{3}\right]\right)\right.$, where $V_{m}$ was maximum respiration rate, $K_{m}$ was Michaelis-Menten constant, and $K_{i}$ was inhibition constant. The model predictions were used to examine the behavior of respiration rates. In general, the respiration rates decreased with increasing $\mathrm{CO}_{2}$, but were little affected by changes in $\mathrm{O}_{2}$. 'Coville' blueberries had the highest respiration rate, followed by 'Blueray' and 'Jersey'. The temperature dependence of the respiration rates followed the Arrhenius relationship.
\end{abstract}

The major causes of spoilage for blueberries are fungal decay and physiological changes (Cappellini et al., 1982). Ceponis et al. (1983) and Smittle et al. (1988) have shown that storing blueberries in a $\mathrm{CO}_{2}$-enriched atmosphere is a fairly effective way to inhibit postharvest decay without fungicidal treatment. Therefore, controlled atmosphere storage (CA) or modified atmosphere packaging (MAP) possibly can serve as an alternative to fungicides to extend the shelf life of fresh blueberries.

Both CA and MAP use modified atmosphere (usually reduced 0 , and elevated $\mathrm{CO}_{2}$ levels) to reduce respiration rates and retard softening and physiological changes in the product. MAP has the advantage of not requiring the expensive equipment that is used by $\mathrm{CA}$ for regulating the gas composition. To maintain constant gas composition in the package, MAP relies on matching the respiration of the product with the permeation rates of the package. The design of MAP requires knowledge of the product (optimum gas concentrations and respiration rates), the package (surface area, film thickness, and film permeability), and the environmental factors (storage temperature and relative humidity). The optimum ranges of $\mathrm{O}_{2}$ and $\mathrm{CO}_{2}$ concentrations can be determined using chemical analysis and/or sensory analysis once the quality attributes of the product are defined. The respiration rates can be measured using the closed system method described by Haggar et al. (1992). After the optimum gas concentrations, respiration rates, and storage conditions are known, the package requirements can be estimated from model predictions (Hayakawa et al. 1975; Lee et al., 1992).

However, the development of MAP of blueberry is impeded by the lack of understanding of the respiration of the fruit. The first objective of this work was to study the respiration rates of three blueberry cultivars as a function of $\mathrm{O}_{2}, \mathrm{CO}_{2}$, and temperature. Recently, Lee et al. (1992) developed and verified a Mi-

Recceived for publication 27 Mar. 1992. Accepted for publication 8 July 1992. Paper no. NJ10117-D-92-2 of the Journal Series, New Jersey Agricultural Experiment Station, Cook College, Dept. of Food Science, Rutgers, the State University of New Jersey, New Brunswick, NJ 08903. This work was supported by Hatch funds. We thank Nick Vorsa of the New Jersey Blueberry \& Cranberry Research Center for useful discussions and for providing us with the blueberries for experiment. The cost of publishing this paper was defrayed in part by the payment of page charges. Under postal regulations, this paper therefore must be hereby marked advertisement solely to indicate this fact.

'Korea Food Research Institute, Baekhyun-dong, Songnam-si, Kyonggi-do, Korea.

${ }^{2}$ Corresponding author: Dept. of Food Science, Rutgers Univ., New Brunswick, NJ 08903.
Table 1. Estimated values for $\mathrm{V}_{\mathrm{m}}, \mathrm{K}_{\mathrm{m}}$, and $\mathrm{K}_{\mathrm{i}}$ at 5,15 , and $25 \mathrm{C}$ using multiple linear regression of Eq. [6]. $r^{2}$ is the coefficient of determination. $^{2}$

\begin{tabular}{|c|c|c|c|c|c|}
\hline Cultivars & $\begin{array}{c}\text { Temp } \\
\left({ }^{\circ} \mathrm{C}\right) \\
\end{array}$ & $\mathrm{V}_{\mathrm{m}}$ & $\mathrm{K}_{\mathrm{m}}$ & $\mathrm{K}_{\mathrm{i}}$ & $r^{2}$ \\
\hline \multicolumn{6}{|c|}{ Parameters for $\mathrm{O}_{2}$ consumption curve } \\
\hline \multirow[t]{3}{*}{ Coville } & 5 & 16.602 & 1.488 & 7.417 & 0.996 \\
\hline & 15 & 68.006 & 0.444 & 2.914 & 0.991 \\
\hline & 25 & 127.356 & 5.200 & 6.684 & 0.990 \\
\hline \multirow[t]{3}{*}{ Blueray } & 5 & 11.802 & 1.593 & 11.725 & 0.998 \\
\hline & 15 & 34.670 & 0.130 & 6.783 & 0.999 \\
\hline & 25 & 76.247 & 0.100 & 11.044 & 0.999 \\
\hline \multirow[t]{3}{*}{ Jersey } & 5 & 9.863 & 2.106 & 7.606 & 0.994 \\
\hline & 15 & 35.868 & 0.678 & 3.296 & 0.996 \\
\hline & 25 & 51.285 & 0.411 & 9.361 & 0.996 \\
\hline \multicolumn{6}{|c|}{ Parameters for $\mathrm{CO}_{2}$ evolution curve } \\
\hline \multirow[t]{3}{*}{ Coville } & 5 & 12.539 & 0.429 & 15.486 & 0.998 \\
\hline & 15 & 51.046 & 0.177 & 4.896 & 0.995 \\
\hline & 25 & 99.032 & 0.520 & 13.502 & 0.996 \\
\hline \multirow[t]{3}{*}{ Blueray } & 5 & 8.956 & 0.705 & 19.648 & 0.999 \\
\hline & 15 & 30.203 & - 0.104 & 9.441 & 0.999 \\
\hline & 25 & 76.049 & 0.125 & 19.057 & 0.997 \\
\hline \multirow[t]{3}{*}{ Jersey } & 5 & 7.347 & 0.797 & 12.693 & 0.995 \\
\hline & 15 & 29.942 & 0.784 & 4.449 & 0.998 \\
\hline & 25 & 48.234 & 0.101 & 16.701 & 0.999 \\
\hline
\end{tabular}

${ }^{2} \mathrm{~V}_{\mathrm{m}}=$ maximum respiration rate; $\mathrm{K}_{\mathrm{m}}=$ Michaelis-Menten constant; $\mathrm{K}_{\mathrm{i}}=$ inhibition constant.

chaelis-Menten enzyme kinetics type respiration model for predicting respiration rate of fresh fruit and vegetables as a function of $\mathrm{O}_{2}$ and $\mathrm{CO}$. The second objective was to test the applicability of this model to the blueberry respiration data obtained from this work.

\section{Materials and Methods}

Sample preparation. Fruits of 'Coville', 'Blueray', and 'Jersey' highbush blueberry (Vaccinium colymbosum L.) were harvested from the New Jersey Blueberry \& Cranberry Research Center, Chatsworth, N.J. The blueberries were picked in early July when $\approx 90 \%$ of the berry surface was blue with $\approx 10 \%$ pink around the scar (Windus et al., 1976) The average weights per berry were $1.61,1.57$, and $1.67 \mathrm{~g}$, and the average widths were 15.3, 15.0, and $15.8 \mathrm{~mm}$ for 'Coville', 'Blueray', and 'Jersey', respectively. Sample temperatures were equilibrated for $3 \mathrm{~h}$ before the experiment was started. 

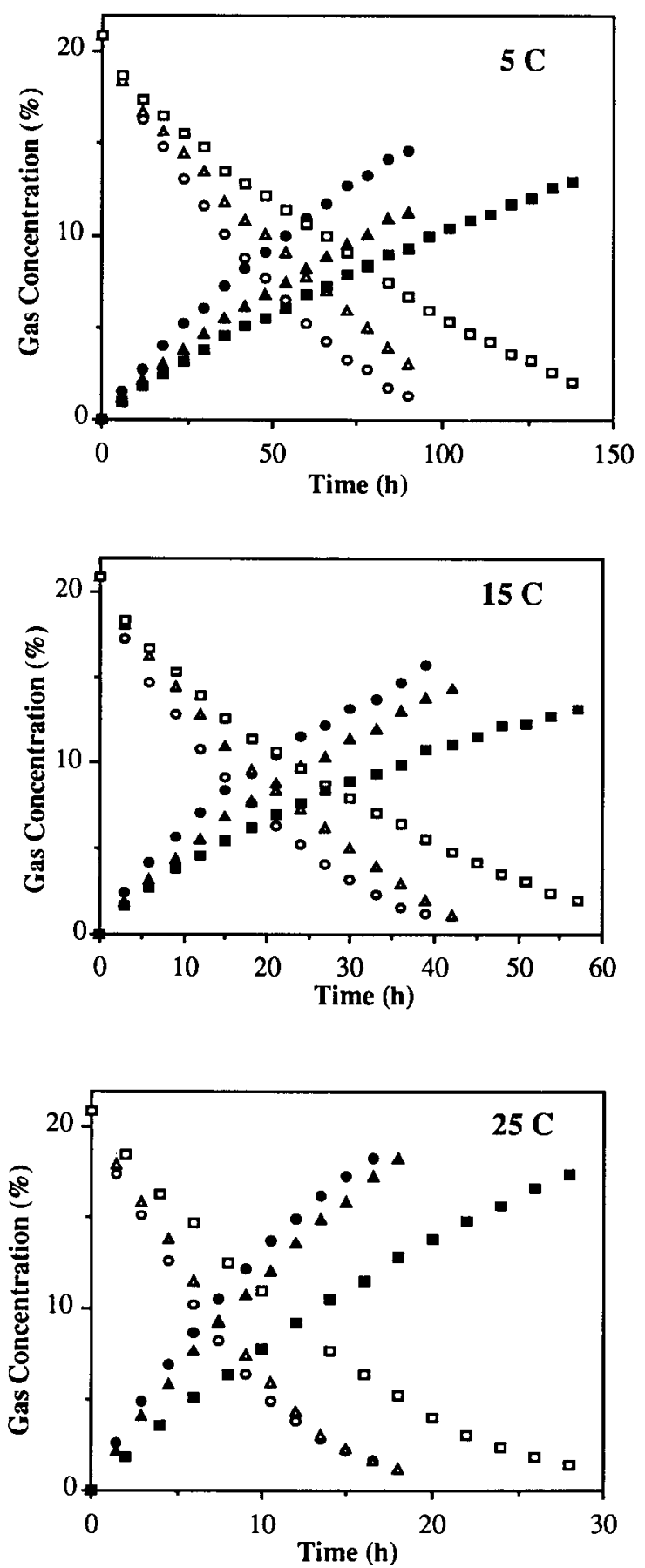

Fig. 1. Plots of $\mathrm{O}_{2}$ and $\mathrm{CO}_{2}$ concentration changes inside closed jars containing blueberries at 5,15 , and $25 \mathrm{C}$. Consumption of $\mathrm{O}_{2}$ : 'Coville' (0), 'Blueray' ( $\mathrm{Cl})$, 'Jersey' (A); evolution of $\mathrm{CO}_{2}$ : 'Coville' ( ) ), 'Blueray' ( $\mathbf{\square})$, 'Jersey' ( $\boldsymbol{\Delta}$ ).

Closed system respiration experiments. Closed system experiments (Haggar et al., 1992; Lee, 1987) were used to measure the respiration rates as a function of $\mathrm{O}_{2}$ and $\mathrm{CO}_{2}$ concentrations at 5, 15, and $25 \mathrm{C}$. One liter glass jars, each containing $\approx 265 \mathrm{~g}$ blueberries, were tightly covered with metal caps equipped with silicone sampling ports. The jars were immediately stored in a refrigerator with temperature controlled within $\pm 0.5 \mathrm{C}$. Head space gas was periodically sampled and the $\mathrm{O}_{2}$ and $\mathrm{CO}_{2}$ concentrations analyzed using a Hewlett Packard 5890A gas chromatograph equipped with a thermal conductivity detector. An Alltech CTR I column (Alltech Associates,

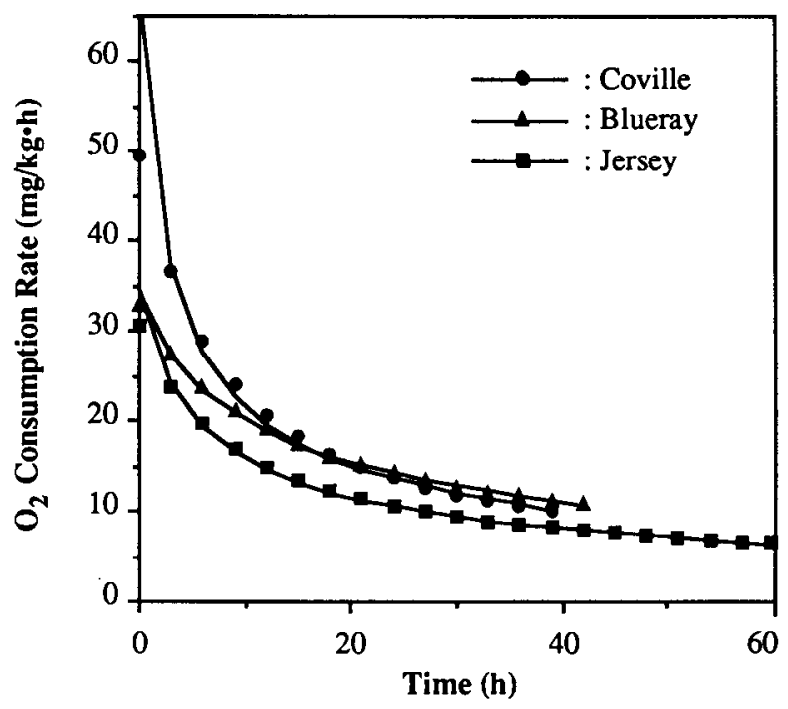

(a)

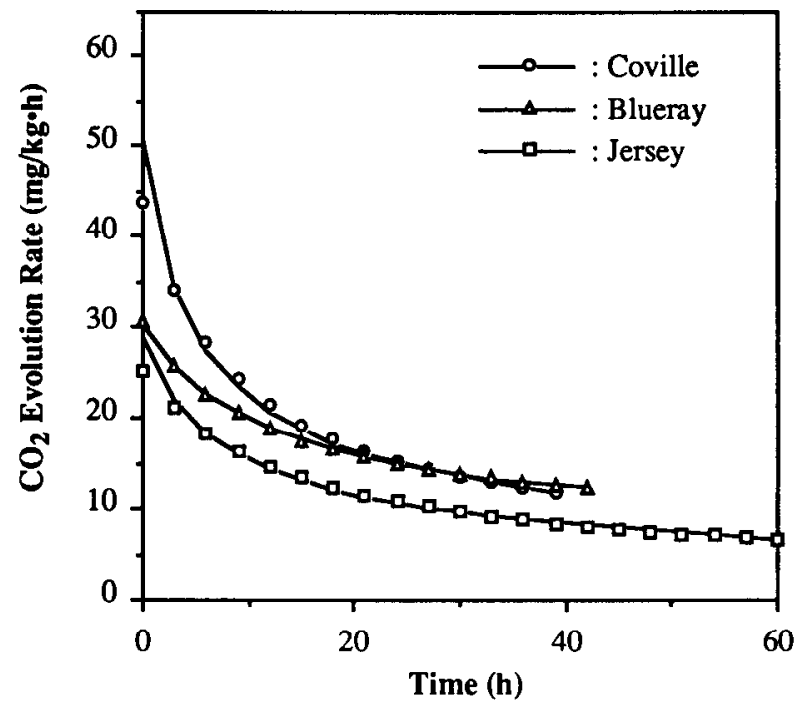

Fig. 2. Actual and predicted respiration rates at $15 \mathrm{C}$; (a) $\mathrm{O}_{2}$ consumption, (b) $\mathrm{CO}_{2}$ evolution. The symbols represent actual data entered into Eqs. [3] and [4], and the solid lines are predicted values from Eq. [6].

Deerfield, Ill.) was used with helium as a carrier gas at a flow rate of $65 \mathrm{ml} \cdot \mathrm{min}^{-1}$ and a column temperature of 30C. Sampling of the head space gas was terminated when the $\mathrm{CO}_{2}$ level inside the jar reached $20 \%$ and/or the $\mathrm{O}_{2}$ level reached $1.5 \%$, because the model is valid only for aerobic respiration (Lee et al., 1992). The measured free volume was 717 to $735 \mathrm{ml}$, and the sample weight was 264 to $265 \mathrm{~g}$.

\section{Results and Discussion}

Respiration rates. The $\mathrm{O}_{2}$ and $\mathrm{CO}_{2}$ concentrations inside the closed jars containing blueberry changed with time at 5, 15, and $25 \mathrm{C}$ in the expected pattern (Fig. 1). Following the procedure of Haggar et al. (1992), we fitted the data with the 

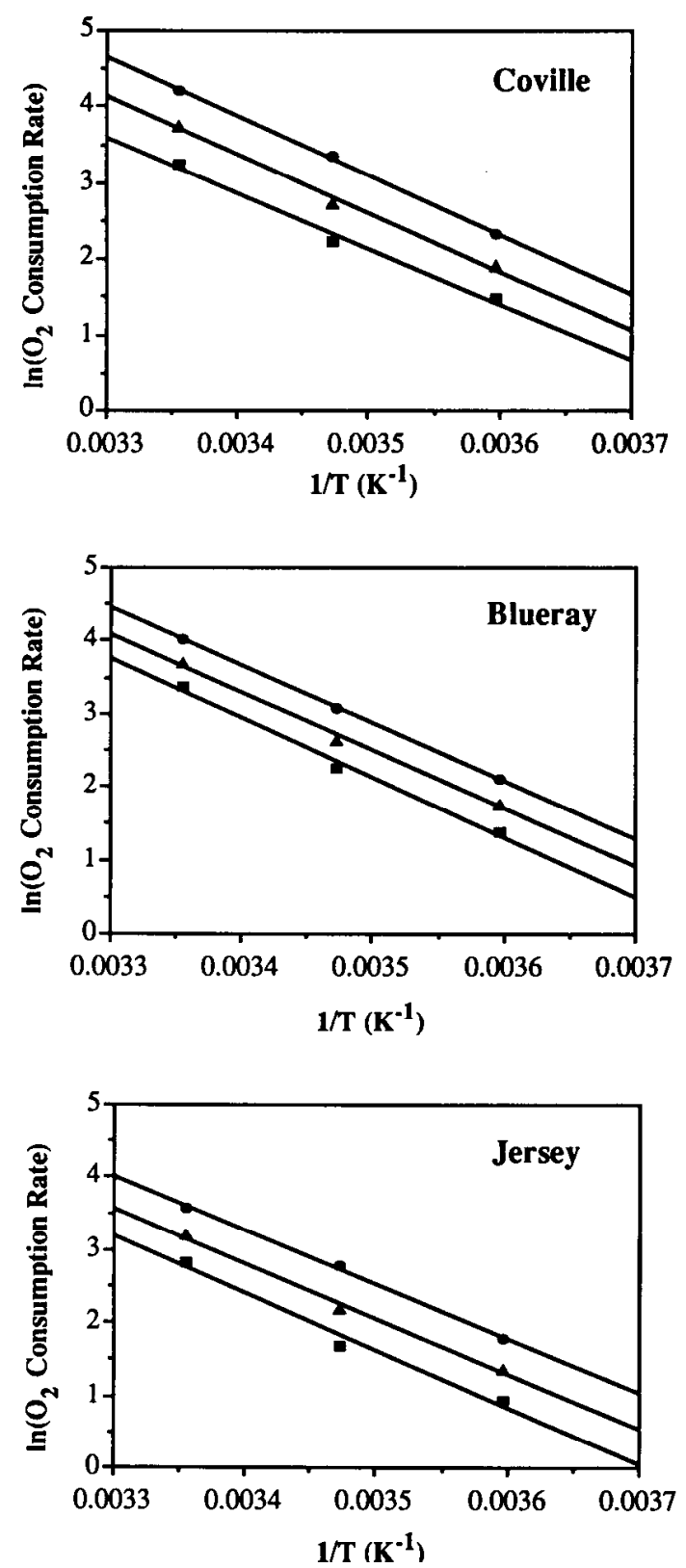

Fig. 3. Effect of temperature on $\mathrm{O}_{2}$ consumption rates under three gas mixtures. ( - ) $18 \% \quad \mathrm{O}_{2}, 4 \% \quad \mathrm{CO}_{2} ;(\boldsymbol{\square}) 10 \% \quad \mathrm{O}_{2}, 10 \% \quad \mathrm{CO}_{2} ;(\boldsymbol{\Delta})$ $4 \% \mathrm{O}_{2}, 18 \% \mathrm{CO}_{2}$.

following equations using the Software Kaleidagraph (Synergy Software, 1990) to perform nonlinear regression analysis.

$$
\begin{gathered}
{\left[\mathrm{O}_{2}\right]=21-\frac{t}{\left(\mathrm{~A}_{1}+\mathrm{B}_{2}\right) \mathrm{C}_{1}}} \\
{\left[\mathrm{C} \mathrm{O}_{2}\right]=\frac{\mathrm{t}}{\left(\mathrm{A}_{2} \mathrm{t}+\mathrm{B}_{2}\right) \mathrm{C}_{2}}}
\end{gathered}
$$

where $\left[\mathrm{O}_{2}\right]$ and $\left[\mathrm{CO}_{2}\right]$ were $\mathrm{O}_{2}$ and $\mathrm{CO}_{2}$ concentrations, repectively; $\mathrm{t}$ was time; $\mathrm{A}_{1}, \mathrm{~A}_{2}, \mathrm{~B}_{1}, \mathrm{~B}_{2}, \mathrm{C}_{1}$, and $\mathrm{C}_{2}$ were adjustable parameters. The regression equations fitted the data very well with coefficients of determination $r^{2}>0.999$. The derivatives
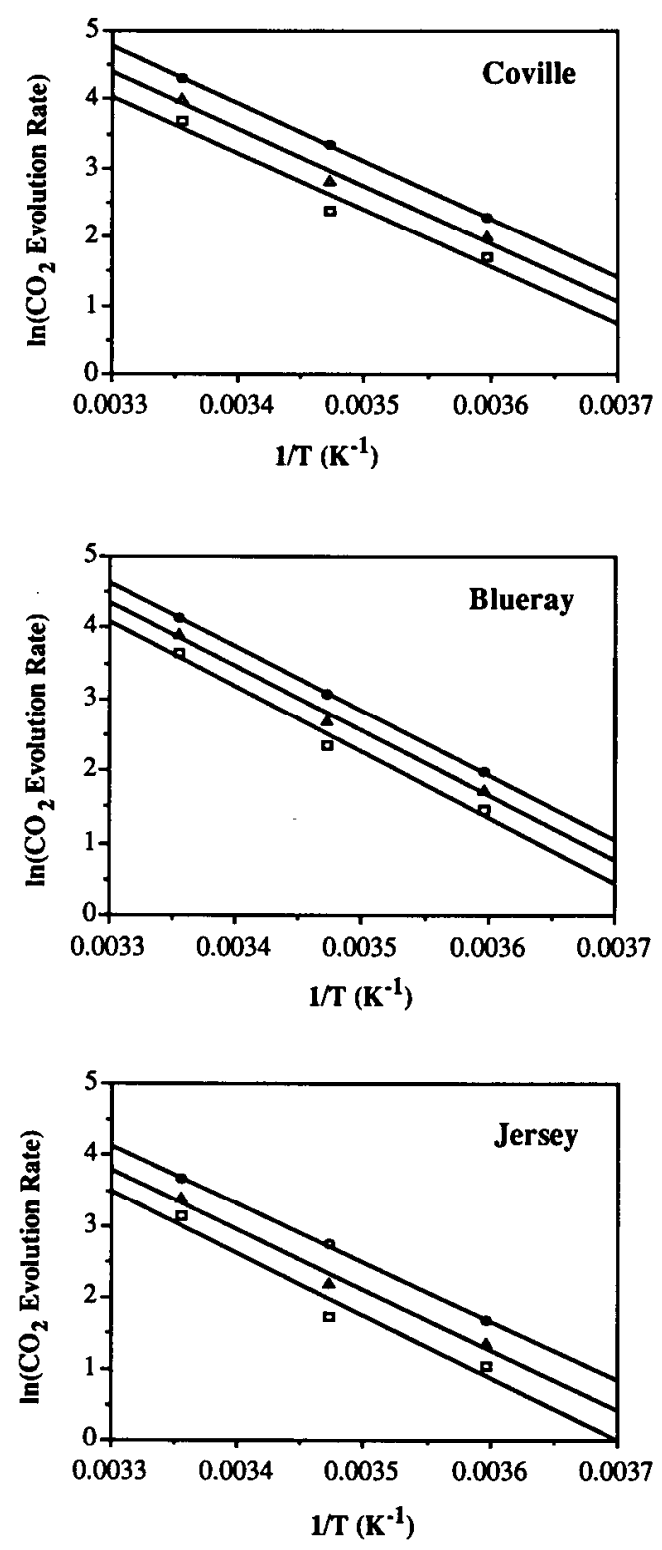

Fig. 4. Effect of temperature on $\mathrm{CO}_{2}$ evolution rates under three gas mixtures. ( ○ ) $18 \% \quad \mathrm{O}_{2}, 4 \% \quad \mathrm{CO}_{2} ;(\square) \quad 10 \% \quad \mathrm{O}_{2}, 10 \% \quad \mathrm{CO}_{2},(\Delta) 4 \%$ $\mathrm{O}_{2}, 18 \% \mathrm{CO}_{2}$.

of the equations were used to obtain the experimental respiration rates $\left(\mathrm{O}_{2}\right.$ consumption and $\mathrm{CO}_{2}$ evolution $)$ :

$$
\begin{aligned}
& \mathrm{r}_{\mathrm{O}_{2}}=-\frac{\mathrm{d}\left[\mathrm{O}_{2}\right]}{\mathrm{dt}}\left(\frac{\mathrm{M}_{\mathrm{O}_{2}} \mathrm{P} \mathrm{V}}{100 \mathrm{R} \mathrm{W} \mathrm{T}}\right) \\
& \mathrm{r}_{\mathrm{CO}_{2}}=\frac{\mathrm{d}\left[\mathrm{CO}_{2}\right]}{\mathrm{dt}}\left(\frac{\mathrm{M}_{\mathrm{CO}_{2}} \mathrm{P} \mathrm{V}}{100 \mathrm{R} \mathrm{W} \mathrm{T}}\right.
\end{aligned}
$$

where $\mathrm{rO}_{2}$ and $\mathrm{rCO}_{2}$ were $\mathrm{O}_{2}$ consumption and $\mathrm{CO}_{2}$ evolution, respectively; $\mathrm{Mo}_{2}$ and $\mathrm{MCO}_{2}$ were molecular weights of $\mathrm{O}_{2}$ and $\mathrm{C} \mathrm{O}_{2}$, respectively; $\mathrm{W}$ was product weight; $\mathrm{P}, \mathrm{V}$, and $\mathrm{T}$ was pressure, free volume, and temperature in the respiration chamber, respectively. As an example, Fig. 2 shows the experimental respiration rates as a function of time at $15 \mathrm{C}$.

Enzyme kinetics respiration model. The respiration rates determined were used to test the recently proposed enzyme kinet- 


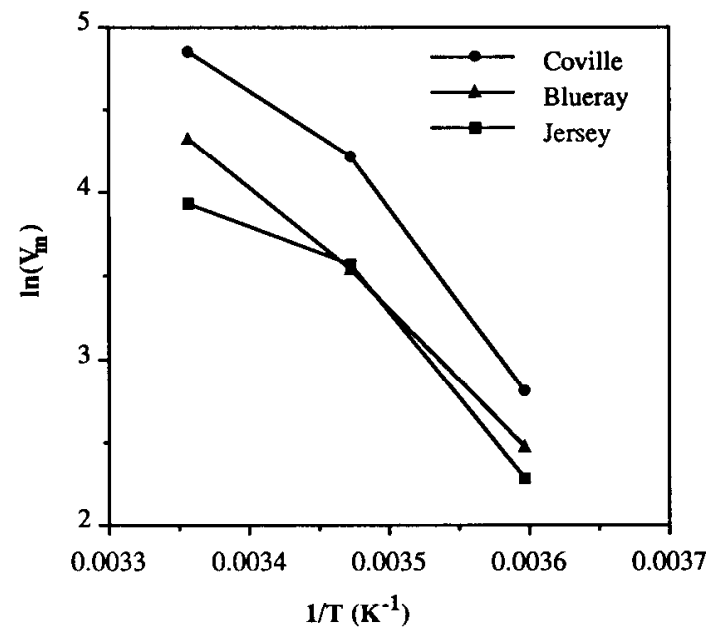

(a)

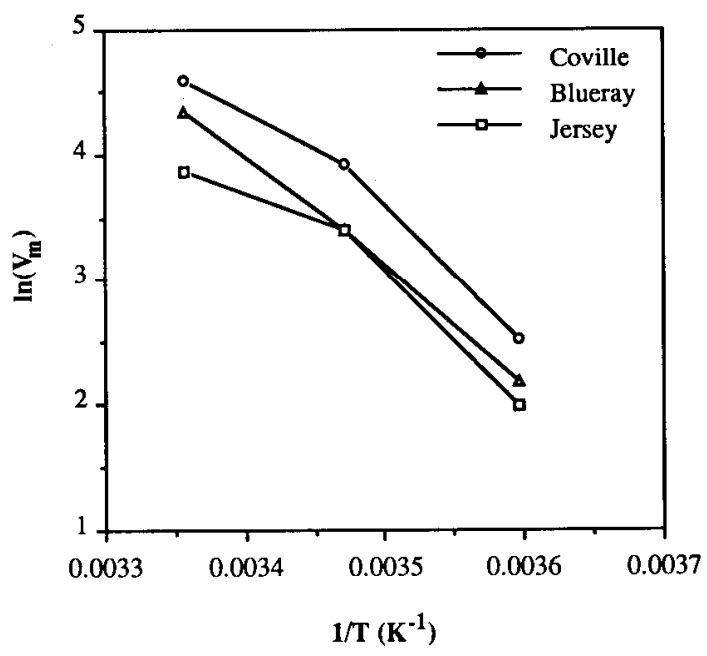

(b)

Fig. 5. Arrhenius plots for the model parameter $\mathrm{V}$; (a) $\mathrm{O}_{2}$ consumption and (b) $\mathrm{CO}_{2}$ evolution. $(\mathrm{V},=$ maximum respiration rate; $\mathrm{T}={ }^{\circ} \mathrm{C} ; \mathrm{K}=$ Kelvin).

ics respiration model of Lee et al. (1992), which can be represented by the equation:

$$
\mathrm{r}=\frac{\mathrm{V}_{\mathrm{m}}\left[\mathrm{O}_{2}\right]}{\mathrm{K}_{\mathrm{m}}+\left(1+\left[\mathrm{CO}_{2}\right] / \mathrm{K}_{\mathrm{i}}\right)\left[\mathrm{O}_{2}\right]}
$$

or its linearlized form

$$
\frac{1}{r}=\frac{1}{V_{m}}+\frac{K_{m}}{V_{m}} \frac{1}{\left[\mathrm{O}_{2}\right]}+\frac{1}{K_{i} V_{m}}\left[\mathrm{CO}_{2}\right]
$$

We used the software JMP (SAS Institute, 1991) to perform multiple linear regression using Eq. [6] to estimate V,, K,, and $\mathrm{K}_{\mathrm{i}}$. The estimated parameter values and the $r^{2}$ are listed in Table 1. With the exception of $\mathrm{K}_{\mathrm{m}}$ value (- 0.104) for blueberry at $15 \mathrm{C}$, all the parameter values are positive, as expected. However, the negative value is quite close to zero. To confirm the applicability of the model, predicted respiration rates were obtained from the estimated parameter values and compared to the actual values. The predicted and the actual values at $15 \mathrm{C}$ com-
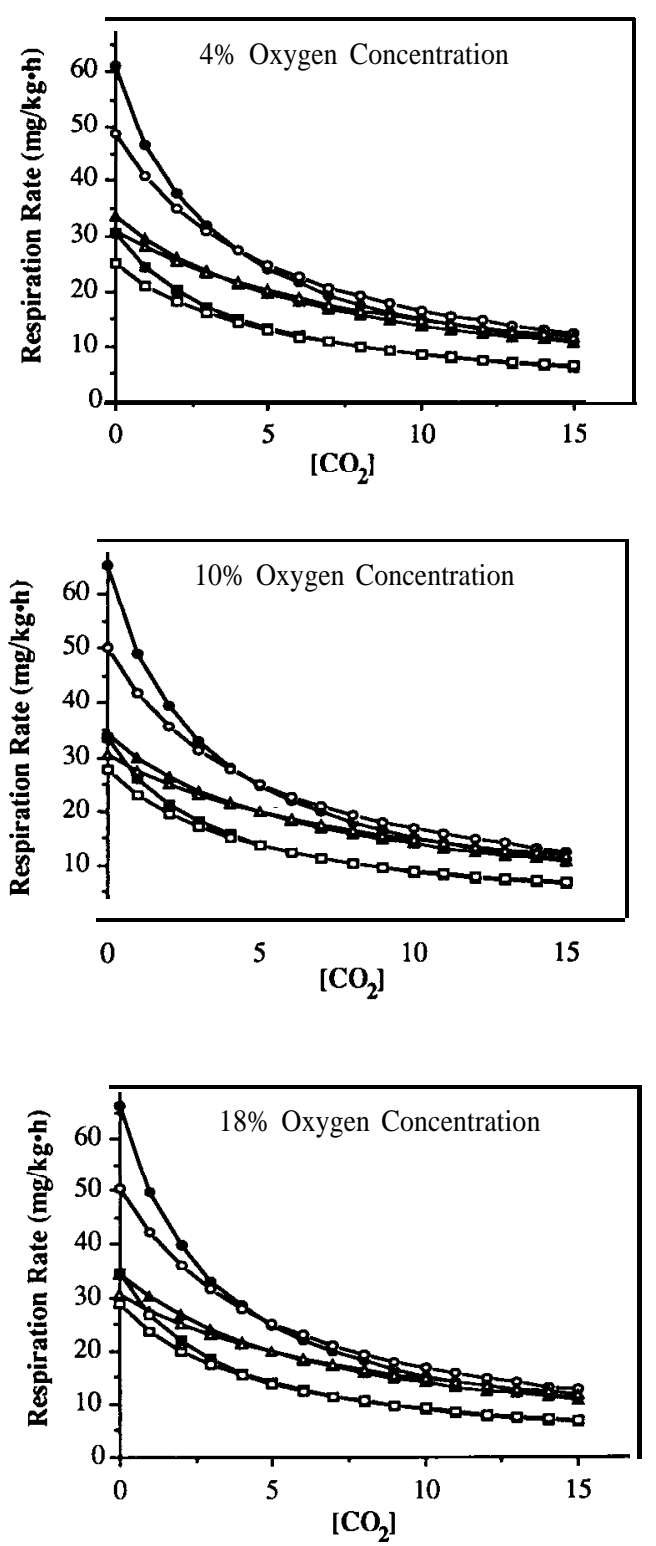

Fig. 6. The model predictions of respiration rates vs. $\mathrm{CO}_{2}$ at $15 \mathrm{C}$ for $4 \%, 10 \%$, and $18 \% \mathrm{O}_{2}$. Consumption of $\mathrm{O}_{2}$ : 'Coville' ( $\bullet$ ), 'Blueray' ( $\mathbf{\square})$, 'Jersey' ( $\boldsymbol{\Delta}$ ); evolution of $\mathrm{CO}_{2}$ : 'Coville' ( (4) ), 'Blueray' ( $\square$ ), ' J e r s e $(\triangle(\triangle)$.

pared very well with each other (Fig. 2). Good agreements also was found for the other two temperatures. These results demonstrate that the enzyme kinetics model, based on noncompetitive inhibition of $\mathrm{CO}_{2}$, applies very well to blueberries.

Effect of temperature on respiration and $V_{m}$. The respiration rates at 5,15 , and $25 \mathrm{C}$ were calculated for three selected $\mathrm{O}_{2}$ and $\mathrm{CO}_{2}$ concentrations using Eq. [6] and the model parameters from Table 1. The Arrhenius equation was used to fit the data, and excellent agreement resulted. The activation energies (E,) were almost independent of the cultivars; the average $\mathrm{E}_{\mathrm{a}}$ for $\mathrm{O}_{2}$ consumption (Fig. 3) was $35.2 \pm 1.2 \mathrm{Kcal} / \mathrm{mole}$, and the average $\mathrm{E}_{\mathrm{a}}$ for $\mathrm{CO}_{2}$ evolution (Fig. 4) was $39.0 \pm 1.6 \mathrm{Kcal} / \mathrm{mole}$. This result supports the suggestion of Haggar et al. (1992) that it may be possible to use only one activation energy for various cultivars of a produce.

The model parameter $\mathrm{V}_{\max }$ was found to increase with temperature. This result is not surprising because $\mathrm{V}_{\max }$ has the physical meaning of being the maximum respiration rate. The 
Arrhenius plots for $\mathrm{V}_{\max }$ are nonlinear and seem to display two regions (Fig. 5). A similar phenomenon was observed in the data of Haggar et al. (1992). This observation may be explained by the following reasoning. There is evidence that high $\mathrm{CO}$, levels suppress respiration by inhibiting certain enzymes such as succinic dehydrogenase (EC 1.3.99.1), cytochrome oxidase (EC 1.9.3.1), and phosphofructokinase (PFK; EC 2.7.1.56) (Kubo et al., 1990). For example, a reduction of PFK activity by elevated $\mathrm{CO}_{2}$ could result from an inhibition of PFK synthesis or by inactivation of preexisting PFK (Kerbel et al., 1990). Thus, $\mathrm{V}_{\max }$ in the enzyme catalyzed reactions depends on several rate constants, each of which may be affected differently by changing temperature (Segel, 1976). Possibly, a different temperature becomes rate limiting at a given reaction step, and consequently the Arrhenius plot may show a change in slope. Although the exact transition temperature is difficult to determine, some changes in reaction rate are apparent at $\approx 15 \mathrm{C}$. Therefore, the estimated $\mathrm{E}_{\mathrm{a}}$ should be considered an apparent or average value.

Model predictions. The model and the parameter values were used to predict the respiration of blueberries at $15 \mathrm{C}$ for $4 \%$, $10 \%$, and $18 \% \mathrm{O}_{2}$. The respiration rates decrease with increasing $\mathrm{CO}_{2}$ but are very little affected by changes in $\mathrm{O}_{2}$. In general, 'Coville' had the highest respiration rate, followed by 'Blueray' and 'Jersey'. As CO, increased, however, the differences in respiration rates among the cultivars decreased. The respiratory quotients $(\mathrm{RQ})$ for all cultivars were $>1.0$ for $\mathrm{CO}_{2}$ concentrations up to $4 \%$ and $\approx 1.0$ at higher $\mathrm{CO}_{2}$ concentrations.

The enzyme kinetics respiration model, based on noncompetitive inhibition of $\mathrm{CO}_{2}$, describes the respiration of the three blueberry cultivars very well. The model predictions indicate that 'Coville' has the highest respiration rate, followed by 'Blueray' and 'Jersey'. Increases in $\mathrm{CO}_{2}$ can greatly decrease respiration, but change in $\mathrm{O}_{2}$ has little effect. The temperature dependence of respiration follows the Arrhenius relationship. The Arrhenius plots for $\mathrm{V}_{\max }$ are nonlinear, indicating the possibility that this parameter may be controlled by several enzyme reactions, and that the rate constants of these reactions are affected differently by changing temperature. From a practical point of view, the model along the estimated parameter values can be used to design modified atmosphere packages for blueberries.

\section{Literature Cited}

Cappellini, R.A. and M.J. Ceponis. 1982. Nature and extent of losses in consumer-grade samples of blueberries in greater New York. HortScience 17:55-56.

Ceponis, M.J. and R.A. Cappellini. 1983. Control of postharvest decays of blueberries by carbon dioxide-enriched atmospheres. Plant Dis. 67:169-170.

Haggar, P.E., D.S. Lee, and K.L. Yam. 1992. Application of an enzyme kinetics based respiration model to closed system experiments for fresh produce. J. Food Proc. Eng. 15:143-157.

Hayakawa, K., Y.S. Henig, and S.G. Gilbert. 197.5. Formulae for predicting gas exchange of fresh produce in polymeric film package. J. Food Sci. 40:186-191.

Kerbel, E.L., A.A. Kader, and R.J. Romani. 1990. Respiratory and glycolytic response of suspension-cultured 'Passe Crassane' pear fruit cells to elevated $\mathrm{CO}_{2}$ concentrations. J. Amer. Soc. Hort. Sci. 115:111-114.

Kubo Y., A. Inaba, and R. Nakamura. 1990. Respiration and $\mathrm{C}_{2} \mathrm{H}_{4}$ production in various harvested crops held in $\mathrm{CO}_{2}$ enriched atmospheres. J. Amer. Soc. Hort. Sci. 115:975-978.

Lee, D.S., P.E. Haggar, J. Lee, and K.L. Yam. 1992. Model for fresh produce respiration in modified atmospheres based on principles of enzyme kinetics. J. Food Sci. 56:1580-1585.

Lee, J. 1987. The design of controlled or modified packaging systems for fresh produce, p. 157. In: J.I. Gray, B.R. Harte, and J. Miltz (eds.). Food product-package compatibility proceedings, Technomic Publishing, Lancaster, Pa.

SAS Institute. 1991. JMP: Software for statistical visualization, version 2. Cary, N.C.

Segel, I.H. 1976. Biochemical calculations, p. 277-279 In: Enzymes 2nd ed. Wiley, New York.

Smittle, D.A. and W.R. Miller. 1988. Rabbiteye blueberry storage life and fruit quality in controlled atmospheres and air storage. J. Amer. Soc. Hort. Sci. 113:723-728.

Synergy Software. 1990. KaleidaGraph, version 2.1. Reading, Pa.

Windus, N.D., V.G. Shutak, and R.E. Gough. 1976. $\mathrm{CO}_{2}$ and $\mathrm{C}_{2} \mathrm{H}_{4}$ evolution by highbush blueberry fruit. HortScience 11:515-517. 